\title{
Corporate engagements with startups: antecedents, models, and open questions for innovation management
}

\author{
Raoni Barros Bagno ${ }^{a}$, Mario Sergio Salerno ${ }^{b}$ (D), Wesley Canedo de Souza Junior ${ }^{a}$ (D), Gina Colarelli O'Connor ${ }^{c}$ \\ a Departamento de Engenharia de Produção, Escola de Engenharia, Universidade Federal de Minas Gerais - UFMG, Belo Horizonte, MG, Brasil

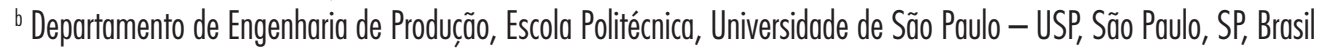 \\ ' Entrepreneurship Division, Babson College, Wellesley, Massachusetts, United States \\ e-mails: raonibagno@dep.ufmg.br; msalerno@usp.br; wesleycanedo@gmail.com; goconnor@babson.edu
}

\begin{abstract}
Corporate Engagements with Startups (CEwS) are Open Innovation initiatives in which large established companies interact with startups aiming at improving innovation performance. Complementary characteristics of established companies (e.g. resource availability, inertia...) and startups (resource scarcity, flexibility, technologies...) are starting points for such engagements. However, large companies and startups are remarkably different so that working together can be overly challenging. Especially for large companies, many intricacies emerge to interact with nascent businesses (e.g. processes, culture, resource sharing, information disclosure, etc.). This study summarizes the current literature on CEwS and identifies the main strands and antecedents of this phenomenon, as well as the main reference models available in the literature. Then, the paper presents and discusses some open questions for innovation management under the perspective of large companies, based on the gaps identified between the presented literature on $\mathrm{CEwS}$ and the organizational debate within the innovation management field. Finally, we present implications for theory and practice and suggest directions for future studies on CEwS.
\end{abstract}

Keywords: corporate engagements with startups, open innovation, innovation management, literature review.

\section{Introduction}

Innovation has been largely considered a mandatory path for companies to stay competitive (Adams et al., 2006; O'Connor et al., 2008; Tidd et al., 2001). Especially in the context of large established companies, efforts aiming at improving innovation performance are in permanent conflict with other demands associated with short-term operational efficiency (Duncan, 1976; O'Connor et al., 2008; O’Reilly 3rd \& Tushman, 2013; Tidd et al., 2001). This is likely to be the most central challenge of innovation management over the last decades.

The concept of Open Innovation, coined by Chesbrough (2003), has remarkably influenced the thoughts in this field. When innovating openly, knowledge flows inbound and outbound a company so that risks and uncertainties associated with innovation projects are gradually mitigated (Chesbrough, 2003; Huizingh, 2011). Notwithstanding, even though an open innovation approach can leverage companies' innovation potential through external ideas, resources, and expertise, the building of a systematic open innovation capability is a result of a long organizational change process (e.g. Chiaroni et al., 2011). Current literature provides us with many alerts regarding the risks for companies when they outsource their innovation capabilities - a misinterpretation that managers often make when they see the opportunities offered by open innovation approaches (c.f. Huizingh, 2011). Therefore, instead of using open innovation to avoid the challenges associated with organizational transformation to innovate, the conduction of efforts towards open innovation requires itself a transformational experience.

In this context, Corporate Engagements with Startups (CEwS) have emerged as a strong and promising form of open innovation. Many studies report growing numbers of companies interacting with startups (Kohler, 2016; Livieratos \& Lepeniotis, 2017; Prashantham \& Kumar, 2019; Weiblen \& Chesbrough, 2015). Largely propelled by the recent advances and diffusion of digital technologies, CEwS have been occurring in many different formats, purposes, and levels of interaction. Generally, for large established companies, CEwS represent a way to mitigate the uncertainties associated with radical innovation; for startups, by turn, CEwS are opportunities to access resources and extra help to propel their business. 
CEwS as a particular field of research is still in its early days and it is largely dedicated to understanding how corporate programs work, basic rules to establish startup engagements and recommendations on how to select partners (Hogenhuis et al., 2016; Selig et al., 2018; Spender et al., 2017). A further understanding of how large established companies organize for systematic engagements with startups, aiming at consolidating open innovation capabilities and leveraging the overall performance in the management of innovation is still not clear. Therefore, to propose connections between startup engagements and innovation management in large companies, we need first to delimitate the antecedents and the models that underlie the current debate on CEwS so that the opportunities to bridge these strands can emerge. Such opportunities come in the form of open questions to be addressed to the innovation management field aiming at generating new insights for academic research and the management practice in large companies.

The present study aims to cope with this challenge. It offers a landscape of the current theoretical approaches on CEwS, identifying their antecedents, the main strands, and the available models. Following, we discuss the gaps between the current CEwS studies and the organizational aspects of innovation management, elucidating implications, and directions for future practice and research from the perspective of large companies.

\section{Method}

To perform a systematic review on the subject of CEwS aiming also to identify its antecedents, we based our steps on previously published efforts in innovation management field concerning literature reviews and document search (Bagno et al., 2017a; Bagno et al., 2017c; Silva et al., 2014). Thus, the bibliography search was firstly done on Sciencedirect and Ebsco Business Source platforms in April 2019. We used the following expression: (startup or start-up or start up or startups or start-ups) AND (engagement or partnership or agreement or acceleration or incubation), filtering the results by the field. As a complementary procedure, we combined the first part of the expression using AND command with (company OR companies OR mnc OR firm OR corporate). After carefully reading titles and abstracts, we obtained 19 articles that potentially could add insights into CEwS subjects. Similar expressions were tried in other academic search platforms with no significant contribution to the initial list except for adding management reports from consulting firms and enterprise organizations available in public domains.

Such a procedure allowed us to recognize the studies of Weiblen \& Chesbrough (2015) (354 citations in Google Scholar, 100 citations in Scopus database on August 10, 2020) and Kohler (2016) (257 citations in Google Scholar,
75 citations in Scopus database on the same date) as central for CEwS current debate. Then we have revisited the academic databases in search of recent articles that cited at least one of these central studies and, again, we filtered the results by reading titles and abstracts, analyzing the affinity with our subject. A snowball approach was also applied along these readings to identify potential insightful papers that were cited frequently across the sample. At last, 66 documents among academic papers, books, and industry reports were judged relevant to a more careful exploration. From those, 52 corresponded to journal articles, and 33 of them were published after Weiblen \& Chesbrough (2015)'s seminal work. As not all of the documents were considered to delineate the general landscape of $\mathrm{CEwS}$ offered in this paper so that Appendix 1 shows details of the complete list of selected documents used to explore the subject.

The list of documents returned from this search revealed that no academic journal concentrated the debate but nine innovation-related journals presented three or more contributions to the final list, as shown in Figure 1.

Borrowing some recommendations for clarity and transparency in systematic reviews from PRISMA(Preferred Reporting Items for Systematic reviews and Meta-Analyses, a standard originally proposed for healthcare field; Liberati et al., 2009; Moher et al., 2009), one important concern lay on the bias - of the search itself and the authors when selecting studies from the database results. We dealt with authors' biases by systematically comparing the overall search for articles and reports made in separate by two different authors of this study, making corrections on the main list when a text emerged with high priority in one list, but not in the other. Such an exercise helped to adjust the individual criteria for selecting documents and also for categorizing strands as well as increased confidence in the final list of papers/reports.

Translating the meaning of bias to the management field, we can assume that search biases might occur in terms of (i) the size of companies involved in the open innovation initiatives and the side of the partnership to take into consideration for analysis; (ii) the theoretical perspective (i.e. the main strands that influence the study and shapes its analysis); (iii) the industrial/economic sector on which the studies might be focused. Since such biases may not be declared in each study, they were then identified throughout the readings and processed in favor of the study's central interests and discussions as follows.

Regarding the first source of bias, although several studies are dedicated to understanding corporate engagements from the view of startups (or small companies as a whole) or even intended to take a program perspective (considering the program design regardless of the organization), we decided to focus on studies that explicitly considered the challenges for large companies in some level. This is so because the 


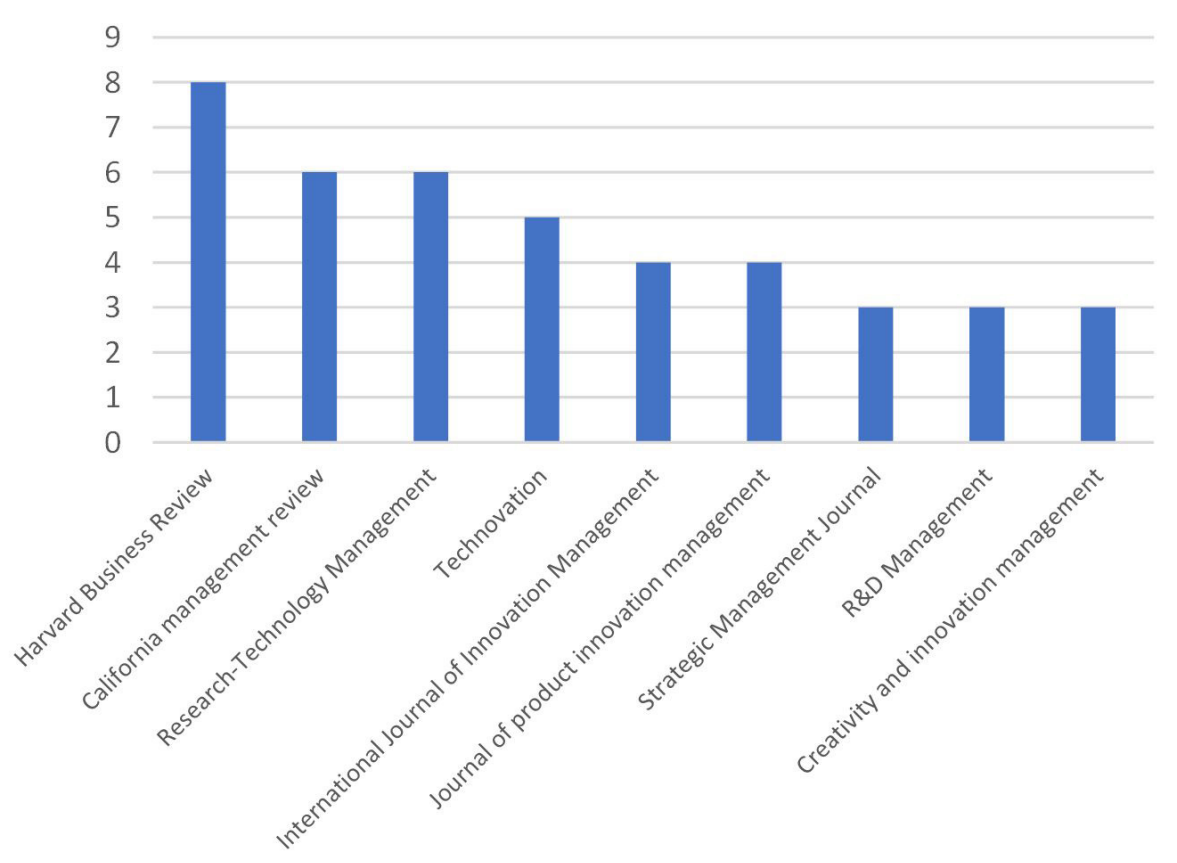

Figure 1. Most retrieved journals for CEwS studies. Source: the authors.

inertia associated with innovation and the trajectory traps that potentially decreases the propensity to engage with change is typical of complex organizations. In line with this aspect, the research question explicitly declared the focus on large organizations, and the search procedure was designed to filter the documents accordingly.

Secondly, in what regards the theoretical lenses from which each study embraces the CEwS, the texts were grouped according to their similarities in terms of approach and strands, which later inspired the topics of the sections 3 and 4.2.

About the third aspect of bias, we could realize that many of the retrieved studies are highly influenced by the dynamics of digital-born companies, in special by the experience and lessons of the so-called FAAMG (Facebook, Apple, Amazon, Microsoft, and Google, also known as The Big Five). Even though we recognize that digital technologies are the main lever of the CEwS phenomenon in the last years (which is discussed in section 4.1), the challenges behind CEwS for systematic innovation is likely to differ dramatically between these experiences and that of large companies of traditional industrial sectors due to similar reasons as those discussed in the first aspect.

These gaps first inspired the topics of section 5, which is designed to bring insights to a broader audience of large companies' practitioners and researchers. Moreover, as the lack of connection between CEwS and systematic innovation management literature became clear we gradually refined the discussion presented in section 5, based on our previous investigations on the subject (e.g. Bagno et al., 2017b; Bagno et al., 2017c; Melo \& Bagno,
2017). Finally, the conclusion section summarizes our final thoughts and directions for future research.

\section{Antecedents of CEwS}

As an emerging field of study, before discussing the contemporary forms and models of CEwS, the identification of the strands that influenced the practice and research on this field is of vital importance to understand the different elements and perspectives highlighted by each theoretical lens to shape the richness of initiatives that we call today as CEwS. Yet, open questions and opportunities to improve the management of innovation from CEwS analysis come from the recognition of its roots and hidden assumptions.

Even though a careful analysis on the literature searched may reveal many hues, branches, and connections among studies, the efforts of categorizing papers, as described in section 2 , led us to recognize at least three broad perspectives to guide our understanding of CEwS' influences and antecedents: one coming mainly from the financial thinking (that gradually steps towards open innovation approaches), other from the exploit-explore dilemma (comprising both studies from strategic and organizational perspectives) and a final one that focuses on the nature of the partnerships. The next subsections present a summary of each one as well as their central ideas.

\subsection{Corporate venturing initiatives and open innovation}

Corporate Venturing Capital initiatives (CVC) conducted by large-sized companies are likely the most influential antecedents of the current debate on CEwS. However, in the early days of Venture Capital investments (VC), these 
initiatives were very transactional, viewed as enablers of financial options, or, at most, associated with direct acquisitions of technology or whole businesses with no other inner interaction between the organizations involved. Today, CVC initiatives are considered as important sources of strategy renewal and new business opportunities (e.g. Basu et al., 2011). Weiblen \& Chesbrough (2015) consider that corporate venture capital along with corporate incubators are the most consolidated models for companies to engage with startups due to their significative diffusion and maturity in the market. Livieratos \& Lepeniotis (2017) argue that we live the fourth wave of $\mathrm{CVC}$, in which the companies' programs are increasingly integrated with open innovation efforts and, as so, they come to get technical and managerial support from several other innovation initiatives.

\subsection{Corporate entrepreneurship and organizational ambidexterity}

Corporate Entrepreneurship, a concept coined in the strategy field, is a way for companies to get incremental value from their current businesses and, simultaneously, bet on promising innovation opportunities (Selig et al., 2018; Shankar \& Shepherd, 2018). This central idea is remarkably similar to that one found in organizational ambidexterity strand (which root in organizational studies) that postulate that a company needs to exploit its current business (i.e. improving operational efficiency, incrementally innovating within their domains) and, at the same time, explore disruptive opportunities (radical innovation, outside the company's domains) (O'Reilly \& Tushman, 2004; Raisch $\&$ Birkinshaw, 2008).

Since established companies are usually biased towards exploitation, Alänge \& Steiber (2018) affirm that engaging with startups could represent a path to thrive in the ambidexterity challenge of incumbent companies by bringing "exploration" closer to the organizational routine. These authors offer a framework of operational modes for ambidexterity based on the successful experiences of large manufacturing companies in their interactions with innovative nascent businesses.

\subsection{Asymmetric partnerships}

Asymmetric Partnerships are those in which the partners are strongly different from each other in terms of size, resources, or commercial experience (Minshall et al., 2010). This is exactly the case when established companies and startups work together, even though this study line investigates the abovementioned partnerships involving large and small companies in general and so, it has developed much before the startup movement got prominence.

The expropriation of resources from the "weak side" of such kind of a partnership is one of the central problems discussed in this study line. According to Freytag (2019), startups and established companies can achieve success in long-term partnerships only if the interests of both sides are properly considered - which is not necessarily obvious in the context of large firms that lead over long and mature value chains.

Long organizational trajectories, strongly marked by verticalized interinstitutional relationships and centralized network governances, frequent use of bargain power, and strictly detailed contracts that seek to predict and rule every single move from suppliers and other partners are examples of factors that highly influence the general mindset applied to partnerships in many large-sized companies (Bagno et al., 2012; Humphrey \& Schmitz, 2000). Although the asymmetric partnerships strand presents many concerns and warnings applicable to corporate-startup partnerships, Minshall et al. (2010) argue that asymmetric relations between large established companies and startups can flourish and provide both sides with economic advantages.

\section{Corporate engagements with startups}

As discussed in previous sections, the increasing numbers of CEwS observed in the last years are highly influenced by the rise, modularity, transversality, accessibility, and decreasing costs of digital technologies. These aspects have fostered many technology entrepreneurship initiatives with high potential to meet the demands of large companies under the pressure for efficiency in the context of industry 4.0 and the impacts of digital transformation over their businesses. Hence, section 4.1 brings some concepts and considerations from this field to pave our understanding of the contemporary forms of CEwS. Following, section 4.2 presents the seminal studies on contemporary CEwS and the main models.

\subsection{The role of digital technologies for contemporary CEwS}

Castells \& Hall (1994) affirmed that cities and regions would have their whole structures changed by three main historical processes, viz, a revolution based on information technologies, so relevant as were the energy sources for the former industrial revolutions; a global economy that comprises elements like capital, management, work, technology, information and markets; and new production patterns in which competitiveness comes to be highly dependent on new knowledge and on the level by which the organizations access and process information properly.

Prashantham \& Kumar (2019) observe a sense of urgency in industries perceiving disruption through digitization. According to Basu et al. (2011), commitment to activities like CVC is greater in industries with rapid technological change, high competitive intensity, and weak appropriability. Moreover, digital platforms and platformoriented companies are currently getting increasing recognition as the main enablers of ecosystem innovations. 
In doing so, a platform leader needs to be able to nurture an entire ecosystem of players (e.g. startups) in mutual relations and diverse combinations to innovate (Accenture, 2015).

Erzurumlu (2018) considers digital technologies as the main driver of the current revolution as they are far from any saturations and have the potential to transform every sector in the economy. The author emphasizes five digital technologies, considered fundamental for businesses in the contemporary context: cloud, big data analytics, cognitive computing, internet of things (IoT), and augmented / virtual reality (AR/ VR). Minsky (2019) highlights that companies of almost all sectors are paying special attention to technologies such as IoT, robotic process automation (RPA), artificial intelligence, VR, and blockchain. Likewise, Alänge \& Steiber (2018) pose that the Internet and cheap information processing have accelerated rates of change and product life cycles in many industries, also fostering new collaborative approaches to innovation with partners outside the firm.

Surely, engagement with startups is not an effort restricted to firms of a specific industrial sector nor startups are all digital. Noteworthy that the so-called "deep techs" - which comprises, for instance, advanced materials, biotechnology, and photonics - have enormous transformation power and have been attracting increasing investments in the CV market (Portincaso et al., 2019). Even so, digital technologies are undoubtedly central to the so reverberating growth of technology entrepreneurship in last years (Prashantham \& Kumar, 2019; Selig et al., 2018) and the majority of studies in CEwS report on cases that keep strong relation to the digital technologies.

Wikhamn \& Styhre (2019) and Hsieh \& Tidd (2012) reinforce that it is different to design an open business model for a small app developer and an innovation for a large biopharmaceutical firm. Native digital companies can be considered today the pioneers in engaging more proactively with startups, and examples are somewhat spread in recent literature (Davenport, 2018; Minsky, 2019; Weiblen \& Chesbrough, 2015). Minsky (2019) observes that big healthcare or construction companies represent sectors reluctant to collaborate with startups, support corporate accelerators, launch a venture capital arm, or even acquire startups. On the other hand, powerful new platform technologies now emerge and have the potential to nurture innovation patterns in the next several decades. Such a phenomenon seems to simultaneously occur in machine learning and quantum computing, but also in genetic sequencing and other biotechs and, together, generate a momentum that drives a new industrial revolution (Innovation Leader, 2019).

\subsection{Models for CEwS}

According to Kohler (2016), companies seek to engage with startups to develop new products and services together, explore new market opportunities, or share technology and talents to solve business challenges. For a startup, the large company may be an important partner to test the product-market fit, leverage efforts to scale-up operations, support product distribution, raise funds or even attract more credibility to the business by sticking the startup to a recognized brand (Kohler, 2016). In addition, Lawton (2019) highlights that engagements with startups can help established companies to foresee their industries' future by the lenses of the entrepreneurs, change the organizational culture towards an agile behavior and reduce inefficiencies and costs. Kaplan (2019) concludes that despite large companies and startups can be considered totally different worlds, their marriage may be the path to sustainable innovation.

The forms by which established companies and startups interact are numerous. Spender et al. (2017) list many adopted mechanisms like CVC, internal incubators, strategic alliances, and joint ventures. Lawton (2019), besides the corporate acceleration programs, cites the bootcamps, sponsorships to entrepreneurs, and direct engagements with previously identified startups in a specific industry. By turn, Minsky (2019) refers to corporate accelerators, direct cooperation with startups and investments, and/or acquisition of startups, whereas Kohler (2016) categorizes CEwS in corporate hackatons, business, and corporate incubators, corporate venturing and mergers, and acquisitions. Weiblen $\&$ Chesbrough (2015) identify four fundamental types of engagements between large companies and startups, which result from crossing two variables: innovation flow (outsidein or inside-out) and equity involvement (Figure 2): Corporate Venturing, Startup Program (Outside-In), Corporate Incubation and Startup Program (Platform).

Although the increasing number of initiatives and studies on CEwS may offer vast possibilities in innovation and entrepreneurship fields, the enthusiasm associated with this idea is also balanced by unsuccessful cases. Engaging large companies with startups comes with complex challenges underlying the dominant discourse of its benefits. Thus, recent research reveals that many CEwS efforts do not reach their goals and are subsequently abandoned (Prashantham \& Yip, 2016; Weiblen \& Chesbrough, 2015). Minshall et al. (2010) alert about the many managerial challenges to overcome before a proper implementation of partnership management between the large company and startups is set. Special efforts are needed to forge such relationships and making them work. Therefore, how to build an organizational capability to systematically partner with startups becomes a relevant challenge in this context (Innovation Leader, 2019; Prashantham \& Kumar, 2019).

Figure 3 shows a conceptual map that summarizes the presented debate on CEwS, emphasizing the gap of interlocution with the field of systematic innovation management - an almost untouched discussion among the CEwS antecedents and that offers the enormous potential of contribution on how companies should organize to better engage with startups. 


\begin{tabular}{|c|c|c|}
\hline & Direction o & iovation Flow \\
\hline & Outside-In & Inside-Out \\
\hline 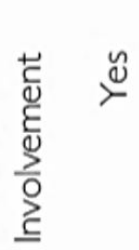 & $\begin{array}{l}\text { Coporate Venturing } \\
\text { Participate in the success of } \\
\text { external innovation and gain } \\
\text { strategic insights into non-core } \\
\text { markets. }\end{array}$ & $\begin{array}{l}\text { Corporate Incubation } \\
\text { Provide a viable path to market } \\
\text { for promising corporate non-core } \\
\text { innovations. }\end{array}$ \\
\hline 言 & $\begin{array}{l}\text { Startup Program (Outside-In) } \\
\text { Insource external innovation to } \\
\text { stimulate and generate corporate } \\
\text { innovation. }\end{array}$ & $\begin{array}{l}\text { Startup Program (Platform) } \\
\text { Spur complementary extemal } \\
\text { innovation to push an existing } \\
\text { corporate innovation } \\
\text { (the platform). }\end{array}$ \\
\hline
\end{tabular}

Figure 2. Types of CEwS. Source: Weiblen \& Chesbrough (2015).

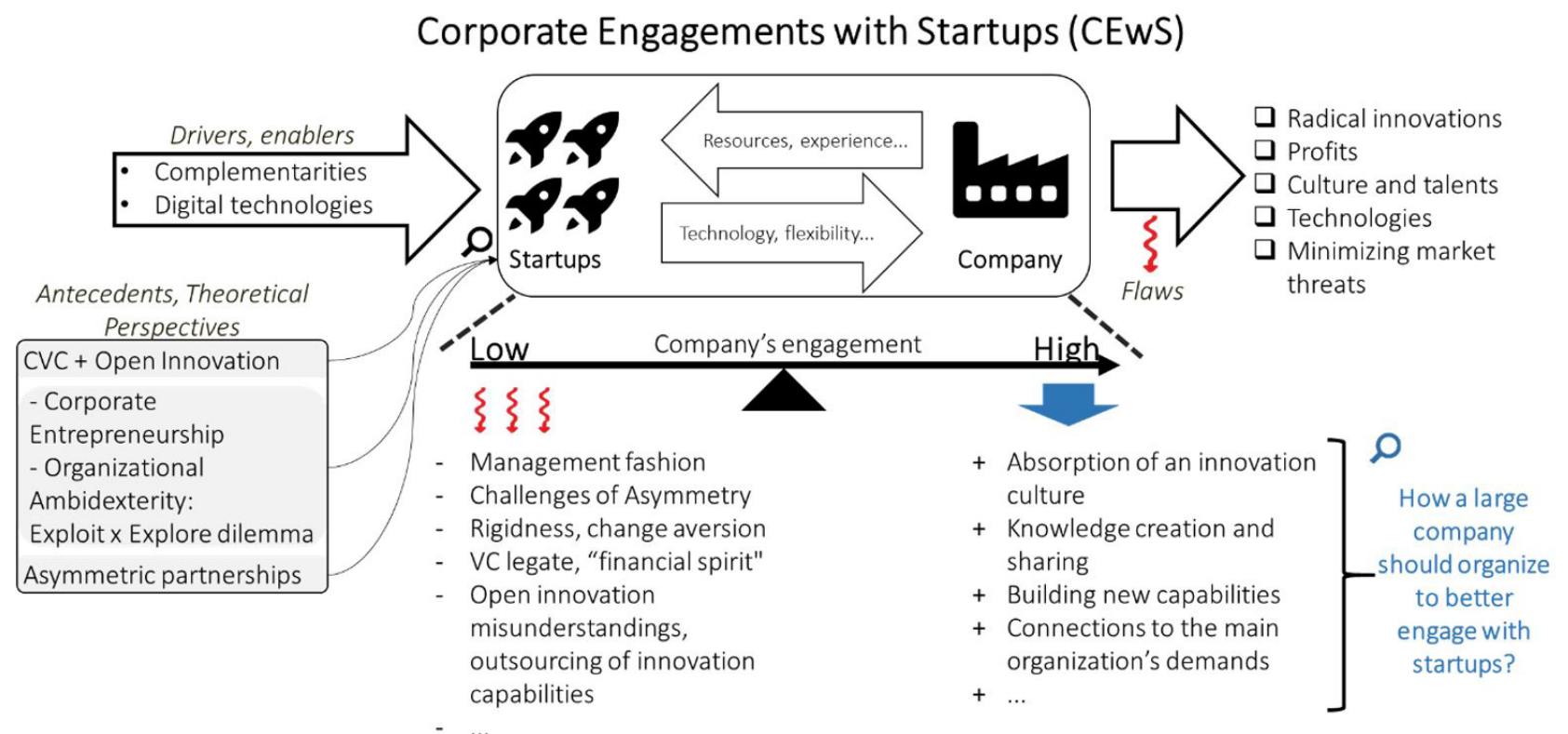

Figure 3. Conceptual map of the general debate on $\mathrm{CEwS}$ and the gap to the field of systematic innovation management. Source: the authors.

\section{Critical Analysis and Implications: open questions for innovation management}

In our journey on CEwS to discuss the antecedents, models, and open questions for innovation management, section 3 covered the antecedents, section 4.1 established the connections with the rise of digital technologies, that appears as the main contextual background of the increasing numbers of CEwS initiatives, and section 4.2 presented the main CEwS models. The present section goes into some open questions that emerge from the gaps identified between the presented literature and the organizational debate within the innovation management field.

Although offering many important insights on how to leverage innovation performance through partnering with startups, the current debate on CEwS largely neglects the subjacent complexity of the internal organizational elements of established companies to allow them to engage with startups effectively and fruitfully in a systematic way. Many of the studies recognize the problem but tend to oversimplify it by, for instance, mentioning the simple need for a maverick champion who should work to broaden the organizational limits and give support to the startups. The next subsections 
present the questions and topics that represented, according to our analysis, the main opportunities to bridge CEwS to innovation management so that new insights for academic research and the management practice in large companies can be fostered.

\subsection{What's touched within the organization? Neglected topics in CEwS' studies concerning the management and organization of large companies}

Selig et al. (2018) note that the external implications of opening the company's innovation process have gained a lot of attention in recent years, while the internal aspects of such an opening still need further investigation. In general, the CEwS literature does not focus on the organizational aspects that result from these engagements, neither go beyond the immediate issues associated with the design and operation of startup programs. Examples are available by examining the objectives of studies such as Kohler (2016, p. 348), Richter et al. (2018), Shankar \& Shepherd (2018), or Kanbach \& Stubner (2016).

The problems of not sufficiently consider the CEwS organizational aspects echo the arguments of Greenwood \& Miller (2010, p. 78) who state that organizational design has been largely neglected in recent times despite its critical importance for organizations' performance. Especially in the field of innovation management, a disproportionate emphasis on management processes would have masked the complexities of building management systems and organizational structures that can catalyze the occurrence of innovations in large companies (O'Connor, 2012, p. 361).

According to Mahmoud-Jouini et al. (2018), a low level of engagement and attraction of resources from the organization's internal environment would prevent good startups from being attracted as well. Therefore, being a "safe" and "attractive" partner is fundamental not only for the success of CEwS itself but also for the connection of these initiatives with other processes and actions within the company. When resources are immobile and incentives misaligned, the innovation process slows down (Freeman \& Engel, 2007).

\subsection{Who's involved? The orchestration of CEwS beyond the champion role}

Younis et al. (2019) report that innovation leadership is usually dispersed throughout the company, resulting in too many top-management roles, temporary committees, and other alternatives. Some studies emphasize the managerial role of driving the interface between the company and startups by identifying an "influential champion" to lead the initiative (Innovation Leader, 2019) or by considering the support given by "dedicated business developers" (Mahmoud-Jouini et al., 2018) who would act as hubs or agents to open the organization's doors in favor of the relationships with startups. Kohler (2016) places corporate accelerator managers as the links between startups and corporations by providing startups with access to the right people within the organization and ensuring that innovations developed externally be used internally. For this purpose, such people should have the ability to work with startups and simultaneously navigate well within the organizational structures. Wikhamn \& Styhre (2019)'s case presents the role of the innovation hub Chief Operating Officer (COO) who was assigned to develop processes and infrastructure for innovation as well as to act as a bridge and gatekeeper to the internal experts of the parent company. Whatever the name assigned to the champion role, our analysis is that the expectations around it are too high.

As noted by Freeman \& Engel (2007), organic forms of innovation in large organizations are difficult to implement and usually rely on the heroic efforts of few individuals who constantly struggle against many internal barriers (e.g. cultural, political, resource disputes), excessive hierarchies and rigidities in processes and rules (Arena et al., 2017; Kelley, 2009; O'Connor et al., 2018). Minsky (2019) argues that what companies do is "innovation theater" when they declare that they are attentive to the startups' scenario but present almost no concrete actions in place. Regarding the work structure, Lawton (2019) points out the need for dedicated teams in the company to work with new partners and reinforces that educating internal stakeholders in this direction requires immense effort. Lastly, the author states that the time and attention that executives from established companies employ to engage with startups dictate the value of the entire initiative and, as a counterpart, they can learn even more than they actually give to the program, which may influence the organization routines as a whole. Therefore, when selecting the ventures to interact with, a company should put its eyes more on startups' people that will be brought inside than on the product/technology they offer (Lawton, 2019).

\subsection{How close, how far? The level of involvement with startups and the tension between separation and integration to the main company}

Most of the initiatives reported in the selected studies describe CEwS-related programs that ran physically separated from the main organization (e.g. Livieratos \& Lepeniotis, 2017; Prashantham \& Kumar, 2019; Selig et al., 2018). In fact, separate structures would allow more autonomy to startup programs and avoid conflicts with the complex organizational structures of large organizations (Kohler, 2016). This scenario, however, contrasts with 
certain expectations normally associated with CEwS, such as offering cultural and behavioral overflows to the company, influencing its internal processes, integrating the talent of people from startups in favor of the company, feeding the company's strategy or establishing regular connections between startups and different internal organizational functions.

In general, programmatic forms would tend to run the innovation process separated from the internal informal networks which are needed to adapt and support innovation - a conflict well consolidated in the organizational ambidexterity strand. In this way, innovations are developed outside the organization's social ecosystem and can be weakened when facing integration challenges (Arena et al., 2017).

\subsection{A good trigger or the whole agenda? The "buts" of riding in the digital transformation}

Although the possibilities for CEwS based on digital technologies are promising, this avenue deserves more scrutiny. Tabrizi et al. (2019) alert that a vision for the organization should drive technology decisions, not the opposite. Thus, the lack of the right mindset and/or keeping inappropriate organizational practices will just cause the digital transformation to magnify the companies' flaws. For instance, not rarely the fear of being replaced installs on people of an organization under digital transformation efforts, so that they may - consciously or not - resist the changes (Tabrizi et al., 2019). Gobble (2018) concludes that all the new beyond-new-product-development challenges like platform initiatives, new business models, digitalization, and servitization demand early the participation of the whole organization. For large ones, that innovation in the management itself to support the advances in technology means a slow and gradual process in which the final intent is to reshape an overly complex social system.

Furthermore, some studies alert that in many CEwS initiatives the technologies are captured late, assigning a bias towards mature technologies (Basu et al., 2011; Shankar $\&$ Shepherd, 2018). Moreover, the rapid advancements as so as the short development lifecycles of products and services associated with digital technologies are remarkable characteristics of this field and shape many of the tools, methodological approaches, and supporting programs of technology entrepreneurship. Regarding this point, Freeman \& Engel (2007, p. 104) alert that "the scales for both dimensions vary substantially across industries, business models, and organizational forms. For internet companies, time may be measured in months; for software firms, in years; and for biotech companies, in decades." Spender et al. (2017) propose that future research consider the link between startups and Open Innovation within different industries.

\section{Conclusions}

This study focused on three objectives: (i) offering an overview of the current literature on Corporate Engagements with Startups, identifying the main strands and antecedents of this phenomenon; (ii) identifying the main reference models available in the recent literature; and, since large companies conduct such initiatives mainly to boost their innovation performance - an objective often conflicting with short-term demands for efficiency -the paper aimed at (iii) presenting and discussing some open questions for innovation management field. To do that, the study applied systematic review techniques (culminating in a visual summary of the general debate), and critical analysis over the results from the perspective of the challenges and gaps they represent for systematic innovation management.

In regard to (i), we found that the antecedents of CEwS can be grouped into three broad categories of studies, viz, corporate venturing initiatives and open innovation (that starts with a purely financial perspective but gradually steers to open innovation approaches); corporate entrepreneurship and organizational ambidexterity (that aggregate studies from both strategic and organizational levels concerning the exploit-explore dilemma); and asymmetric partnerships (that focus on the nature of the partnerships performed between actors and their dissimilarities). Concerning (ii), even though the corporate acceleration and corporate incubation models have received much attention, mainly due to the fact that these models carry a legate from their older forms in non-corporative settings, a diversified group of studies emerged in the last five years exploring many forms of engagement, in single or combined applications, serving multiple stakeholders and objectives of the companies. Lastly, regarding (iii), as the main open questions and challenges for using CEwS as a lever to systematic innovation in large companies, we point the need of unveiling the organizational elements behind the conduction of CEwS initiatives; the limitation of the single champion approach to establish innovation and startup engagement as permanent disciplines in the organization; the trade-off in placing the CEwS initiative too close or too far from the main organization to properly balance the access to resources and vulnerability to constrains; and the potential traps of setting the whole dynamics of innovation management by the digital technologies' agenda.

Above all, the informational economy, as defended by Castells \& Hall (1994), would be characterized by new organizational forms, an idea that holds implications for both the internal structure of established firms and the interorganizational forms of innovating. Thus, more horizontal networks among companies and other agents (such as startups) and more flexible and specialized production systems should emerge. 
Corporate Engagement with Startups is an open innovation modality that has gained enormous emphasis in a context of rapid evolution, diffusion, and access to technologies - especially the digital ones - in intercession with the advent of the new industrial revolution (i.e. Industry 4.0). Numbers related to these engagements are increasing and point to a scenario in which CEwS become one of the main forms of open innovation. However, the field is still embryonic and there are many opportunities for research and further study in both theory and practice.

Above all, it was evidenced that more dialogue between CEwS studies and the field of innovation management is desirable to move forward the research and practice. Such interaction can enrich the debate and subsidize more complex and lasting network arrangements in favor of systematic innovation.

\section{Acknowledgements}

This study was financed in part by the Coordenação de Aperfeiçoamento de Pessoal de Nível Superior - Brasil (CAPES) - Finance Code 001.

\section{References}

Accenture. (2015). Harnessing the power of Entrepreneurs to Open Innovation - The Digital Collaboration Index. 24. Retrieved in 2019, Aug 16, from https://www.accenture. com/us-en/ /media/Accenture/next-gen/B20/AccentureG20-YEA-2015-Open-Innovation-Executive-Summary.pdf

Adams, R., Bessant, J., \& Phelps, R. (2006). Innovation management measurement: A review. International Journal of Management Reviews, 8(1), 21-47.

Alänge, S., \& Steiber, A. (2018). Three operational models for ambidexterity in large corporations. Triple Helix (Heidelberg), 5(1), 5.

Arena, M., Cross, R., Sims, J., \& Uhl-Bien, M. (2017). How to catalyze innovation in your organization. MIT Sloan Management Review, 58(4), 38-48.

Bagno, R. B., Leiva, T. L., \& de Oliveira, L. G. H. (2017a). Innovation management: lessons learned from innovation diagnostic tools. Product: Management \& Development, 14(1), 12-21.

Bagno, R. B., Salerno, M. S., Amato Neto, J., \& Silva, D. (2012). Innovation and technological competence building in Brazilian automotive industry subsidiaries from the perspective of interorganizational networks. In Proceedings of the 20th International GERPISA Colloquium. GERPISA.

Bagno, R. B., Salerno, M. S., \& Dias, A. V. C. (2017b). Innovation as a new organizational function: evidence and characterization from large industrial companies in Brazil. Production, 27, 1-13.
Bagno, R. B., Salerno, M. S., \& Silva, D. O. (2017c). Models with graphical representation for innovation management: a literature review. $R \& D$ Management, 47(4), 637-653.

Basu, S., Phelps, C., \& Kotha, S. (2011). Towards understanding who makes corporate venture capital investments and why. Journal of Business Venturing, 26(2), 153-171. http://dx.doi. org/10.1016/j.jbusvent.2009.07.001.

Castells, M., \& Hall, P. (1994). Technopoles of the world: the making of twenty-first-century industrial complexes. London; New York: Routledge.

Chesbrough, H. W. (2003). Open Innovation: The new imperative for creating and profiting from technology. Boston, MA: Harvard Business School Press.

Chiaroni, D., Chiesa, V., \& Frattini, F. (2011). The Open Innovation Journey: how firms dynamically implement the emerging innovation management paradigm. Technovation, 31(1), 34-43.

Davenport, T. H. (2018). The AI Advantage: How to put the artificial intelligence revolution to work. Cambridge, MA: MIT Press.

Duncan, R. B. (1976). The ambidextrous organization: Designing dual structures for innovation. The management of organization, 1, 167-188.

Erzurumlu, S. (2018, November). 5 Digital Technologies Every Business Manager Must Understand. Skylife, pp. 92-96. Retrieved in 2019, June 5, from https://www.skylife.com/ en/2018-11-business/5-digital-technologies-every-businessmanager-must-understand

Freeman, J., \& Engel, J. S. (2007). Models of innovation: startups and mature corporations. California Management Review, 50(1), 94-119.

Freytag, R. (2019). Strategic negotiations: three essentials for successful partnerships with startups. Strategy and Leadership, 47(1), 19-25. http://dx.doi.org/10.1108/sl-112018-0115.

Gobble, M. M. (2018). The Importance of Management Innovation. Research-Technology Management, 61(6), 54-58. Retrieved in 2019, May 3, from https://link. gale.com/apps/doc/A561883617/EAIM?u=mlin_m babson\&sid=EAIM\&xid=0a776331

Greenwood, R., \& Miller, D. (2010). Tackling design anew: getting back to the heart of organizational theory. The Academy of Management Perspectives, 24(4), 78-88.

Hogenhuis, B. N., van den Hende, E. A., \& Hultink, E. J. (2016). When Should Large Firms Collaborate with Young Ventures? Understanding young firms' strengths can help firms make the right decisions around asymmetric collaborations. Research Technology Management, 59(1), $39-47$. 
Hsieh, K.-N., \& Tidd, J. (2012). Open versus closed new service development: the influences of project novelty. Technovation, 32(11), 600-608. https://doi.org/https://doi. org/10.1016/j.technovation.2012.07.002

Huizingh, E. K. (2011). Open innovation: state of the art and future perspectives. Technovation, 31(1), 2-9.

Humphrey, J., \& Schmitz, H. (2000). Governance and Upgrading in Global Value Chains, a background paper for the Bellagio Value Chain Workshop. Sussex: University of Sussex.

Innovation Leader (2019). Startup engagement: best practices for large organizations (report excerpt). Ipswich, MA: I. Leader.

Kanbach, D. K., \& Stubner, S. (2016). Corporate accelerators as recent form of startup engagement: the what, the why, and the how. Journal of Applied Business Research, 32(6), 1761.

Kaplan, S. (2019, May 2). How big companies \& startups use "Co-Creation" to innovate. INC. Retrieved in 2019, May 3, from https://www.inc.com/soren-kaplan/how-bigcompanies-amp-startups-use-co-creation-to-innovate. html

Kelley, D. (2009). Adaptation and organizational connectedness in corporate radical innovation programs. Journal of Product Innovation Management, 26(5), 487-501.

Kohler, T. (2016). Corporate accelerators: building bridges between corporations and startups. Business Horizons, 59(3), 347-357. http://dx.doi.org/10.1016/j.bushor.2016.01.008.

Lawton, J. (2019). What to expect from your corporate accelerator. Innovation Leader Pointers, (June), 19-21.

Liberati, A., Altman, D. G., Tetzlaff, J., Mulrow, C., Gøtzsche, P. C., Ioannidis, J. P., Clarke, M., Devereaux, P. J., Kleijnen, J., \& Moher, D. (2009). The PRISMA statement for reporting systematic reviews and meta-analyses of studies that evaluate health care interventions: explanation and elaboration. Journal of Clinical Epidemiology, 62(10), e1-e34.

Livieratos, A. D., \& Lepeniotis, P. (2017). Corporate venture capital programs of European electric utilities: Motives, trends, strategies and challenges. The Electricity Journal, 30(2), 30-40. http://dx.doi.org/10.1016/j.tej.2017.01.006.

Mahmoud-Jouini, S. B., Duvert, C., \& Esquirol, M. (2018). Key Factors in Building a Corporate Accelerator Capability: developing an effective corporate accelerator requires close attention to the relationships between startups and the sponsoring company. Research Technology Management, 61(4), 26-34.

Melo, J. C. F., \& Bagno, R. B. (2017). Atribuições de um time dedicado à gestão da inovação em um grupo industrial brasileiro: um estudo longitudinal baseado em eventos. Revista Produção Online, 17(2), 482-506.

Minshall, T., Mortara, L., Valli, R., \& Probert, D. (2010). Making "asymmetric" partnerships work. Research Technology Management, 53(3), 53-63.

Minsky, C. (2019). Big corporates are only interested in "innovation theatre". Sifted. Retrieved in 2019, May12, from https://sifted.eu/articles/big-european-companiesstartups-deloitte-survey/

Moher, D., Liberati, A., Tetzlaff, J., Altman, D. G., \& Group, P. (2009). Preferred reporting items for systematic reviews and meta-analyses: the PRISMA statement. PLoS Medicine, 6(7), e1000097.

O’Connor, G. C. (2012). Innovation: from process to function. Journal of Product Innovation Management, 29(3), 361363.

O’Connor, G. C., Corbett, A. C., \& Peters, L. S. (2018). Beyond the champion: institutionalizing innovation through people. Stanford, CA: Stanford University Press.

O’Connor, G. C., Leifer, R., Paulson, A. S., \& Peters, L. S. (2008). Grabbing Lightning: Building a Capability for Breakthrough Innovation. San Francisco, CA: John Wiley \& Sons.

O'Reilly, C. A., \& Tushman, M. L. (2004). The ambidextrous organization. Harvard Business Review, 82(4), 74.

O’Reilly 3rd, C. A., \& Tushman, M. L. (2013). Organizational ambidexterity: Past, present, and future. The Academy of Management Perspectives, 27(4), 324-338.

Portincaso, M., Tour, A. 1., \& Soussan, P. (2019, March 14). The dawn of the deep tech ecosystem. BCG Henderson Institute. Retrieved in 2019, April 2, from https://www. bcg.com/publications/2019/dawn-deep-tech-ecosystem. aspx

Prashantham, S., \& Kumar, K. (2019). Engaging with startups: MNC Perspectives. IIMB Management Review, http:// dx.doi.org/10.1016/j.iimb.2019.01.003.

Prashantham, S., \& Yip, G. S. (2016, December 2). Engaging with startups in emerging markets. MIT Sloan.

Raisch, S., \& Birkinshaw, J. (2008). Organizational ambidexterity: Antecedents, outcomes, and moderators. Journal of Management, 34(3), 375-409.

Richter, N., Jackson, P., \& Schildhauer, T. (2018). Outsourcing creativity: an abductive study of open innovation using corporate accelerators. Creativity and Innovation Management, 27(1), 69-78.

Selig, C. J., Gasser, T., \& Baltes, G. H. (2018). How corporate accelerators foster organizational transformation: an internal perspective (pp. 1-9). Stuttgart, Germany: IEEE. https://doi.org/10.1109/ice.2018.8436287. 
Shankar, R. K., \& Shepherd, D. A. (2018). Accelerating strategic fit or venture emergence: different paths adopted by corporate accelerators. Journal of Business Venturing, http://dx.doi.org/10.1016/j.jbusvent.2018.06.004.

Silva, D. O. d., Bagno, R. B., \& Salerno, M. S. (2014). Models for innovation management: review and analysis of the literature. Production, 24(2), 477-490.

Spender, J.-C., Corvello, V., Grimaldi, M., \& Rippa, P. (2017). Startups and open innovation: a review of the literature. European Journal of Innovation Management, 20(1), 4-30.

Tabrizi, B., Lam, E., Girard, K., \& Irvin, V. (2019). Digital transformation is not about technology. Harvard Business Review, 13.
Tidd, J., Bessant, J., \& Pavitt, K. (2001). Managing innovation integrating technological, market and organizational change. Chichester, UK: John Wiley and Sons.

Weiblen, T., \& Chesbrough, H. W. (2015). Engaging with startups to enhance corporate innovation. California Management Review, 57(2), 66-90.

Wikhamn, B. R., \& Styhre, A. (2019). Corporate hub as a governance structure for coupled open innovation in large firms. Creativity and Innovation Management, 28(4), 450-463.

Younis, Z., Desai, A., \& Sigal, M. (2019). Unlocking innovation through startup engagement: best practices from leading global corporations. 500. Retrieved in 2019, May 3, from http://go.500.co/unlockinginnovation 
Appendix 1 - Complete reference list used for CEwS studies after the search process

\begin{tabular}{|c|c|c|c|c|c|}
\hline \# & AUTHORS & YEAR & TITLE & TYPE & SOURCE \\
\hline 1 & R. A. Burgelman & 1984 & $\begin{array}{l}\text { Designs for corporate entrepreneurship in } \\
\text { established firms }\end{array}$ & Journal Article & $\begin{array}{l}\text { California management } \\
\text { review }\end{array}$ \\
\hline 2 & $\begin{array}{l}\text { M. T. Hansen, H. W. } \\
\text { Chesbrough, N. Nohria and } \\
\text { D. N. Sull }\end{array}$ & 2000 & $\begin{array}{l}\text { Networked incubators. Hothouses of the } \\
\text { new economy }\end{array}$ & Journal Article & Harvard business review \\
\hline 3 & H. W. Chesbrough & 2002 & Making sense of corporate venture capital & Journal Article & Harvard business review \\
\hline 4 & R. C. Sampson & 2007 & $\begin{array}{l}\text { R\&D alliances and firm performance: The } \\
\text { impact of technological diversity and alliance } \\
\text { organization on innovation }\end{array}$ & Journal Article & $\begin{array}{l}\text { Academy of management } \\
\text { journal }\end{array}$ \\
\hline 5 & J. Freeman and J. S. Engel & 2007 & $\begin{array}{l}\text { Models of innovation: Startups and mature } \\
\text { corporations }\end{array}$ & Journal Article & $\begin{array}{l}\text { California Management } \\
\text { Review }\end{array}$ \\
\hline 6 & $\begin{array}{l}\text { R. Katila, J. D. Rosenberger } \\
\text { and K. M. Eisenhardt }\end{array}$ & 2008 & $\begin{array}{l}\text { Swimming with Sharks: Technology } \\
\text { Ventures, Defense Mechanisms and } \\
\text { Corporate Relationships }\end{array}$ & Journal Article & $\begin{array}{l}\text { Administrative Science } \\
\text { Quarterly }\end{array}$ \\
\hline 7 & $\begin{array}{l}\text { S. Prashantham and J. } \\
\text { Birkinshaw }\end{array}$ & 2008 & $\begin{array}{l}\text { Dancing with gorillas: How small companies } \\
\text { can partner effectively with MNCs }\end{array}$ & Journal Article & $\begin{array}{l}\text { California management } \\
\text { review }\end{array}$ \\
\hline 8 & $\begin{array}{l}\text { T. Minshall, L. Mortara, R. } \\
\text { Valli and D. Probert }\end{array}$ & 2010 & Making "asymmetric" partnerships work & Journal Article & $\begin{array}{l}\text { Research-Technology } \\
\text { Management }\end{array}$ \\
\hline 9 & $\begin{array}{l}\text { S. Basu, C. Phelps and S. } \\
\text { Kotha }\end{array}$ & 2011 & $\begin{array}{l}\text { Towards understanding who makes corporate } \\
\text { venture capital investments and why }\end{array}$ & Journal Article & $\begin{array}{l}\text { Journal of Business } \\
\text { Venturing }\end{array}$ \\
\hline 10 & $\begin{array}{l}\text { S. Anokhin, D. Örtqvist, S. } \\
\text { Thorgren and J. Wincent }\end{array}$ & 2011 & $\begin{array}{l}\text { Corporate venturing deal syndication and } \\
\text { innovation: the information exchange } \\
\text { paradox }\end{array}$ & Journal Article & Long Range Planning \\
\hline 11 & P. Carbone & 2011 & $\begin{array}{l}\text { Acquisition integration models: How large } \\
\text { companies successfully integrate startups }\end{array}$ & Journal Article & $\begin{array}{l}\text { Technology Innovation } \\
\text { Management Review }\end{array}$ \\
\hline 12 & H. W. Chesbrough & 2012 & $\begin{array}{l}\text { GE's ecomagination challenge: An } \\
\text { experiment in open innovation }\end{array}$ & Journal Article & $\begin{array}{l}\text { California management } \\
\text { review }\end{array}$ \\
\hline 13 & B. Leten and W. Van Dyck & 2012 & $\begin{array}{l}\text { Corporate venturing: Strategies and success } \\
\text { factors }\end{array}$ & Journal Article & $\begin{array}{l}\text { Review of Business and } \\
\text { Economic Literature }\end{array}$ \\
\hline 14 & L. Diestre and N. Rajagopalan & 2012 & $\begin{array}{l}\text { Are all 'sharks' dangerous? new } \\
\text { biotechnology ventures and partner selection } \\
\text { in R\&D alliances }\end{array}$ & Journal Article & $\begin{array}{l}\text { Strategic Management } \\
\text { Journal }\end{array}$ \\
\hline 15 & K.-N. Hsieh and J. Tidd & 2012 & $\begin{array}{l}\text { Open versus closed new service development: } \\
\text { The influences of project novelty }\end{array}$ & Journal Article & Technovation \\
\hline 16 & $\begin{array}{l}\text { L. Pérez, J. Florin and J. } \\
\text { Whitelock }\end{array}$ & 2012 & $\begin{array}{l}\text { Dancing with elephants: The challenges of } \\
\text { managing asymmetric technology alliances }\end{array}$ & Journal Article & $\begin{array}{l}\text { The Journal of High } \\
\text { Technology Management } \\
\text { Research }\end{array}$ \\
\hline 17 & S. Blank & 2013 & Why the lean start-up changes everything & Journal Article & Harvard business review \\
\hline 18 & $\begin{array}{l}\text { B. Battistini, F. Hacklin and } \\
\text { P. Baschera }\end{array}$ & 2013 & $\begin{array}{l}\text { The state of corporate venturing: Insights } \\
\text { from a global study }\end{array}$ & Journal Article & $\begin{array}{l}\text { Research-Technology } \\
\text { Management }\end{array}$ \\
\hline 19 & A. Onetti & 2014 & $\begin{array}{l}\text { Scaleups. When does a Startup turn into a } \\
\text { Scaleup }\end{array}$ & $\begin{array}{l}\text { Electronic } \\
\text { Article }\end{array}$ & \\
\hline 20 & N. Sharif and H.-H. H. Tang & 2014 & $\begin{array}{l}\text { New trends in innovation strategy at Chinese } \\
\text { universities in Hong Kong and Shenzhen }\end{array}$ & Journal Article & $\begin{array}{l}\text { International Journal of } \\
\text { Technology Management }\end{array}$ \\
\hline 21 & R. Vandaie and A. Zaheer & 2014 & $\begin{array}{l}\text { Surviving bear hugs: Firm capability, large } \\
\text { partner alliances, and growth }\end{array}$ & Journal Article & $\begin{array}{l}\text { Strategic Management } \\
\text { Journal }\end{array}$ \\
\hline 22 & $\begin{array}{l}\text { C. S. Dempwolf, J. Auer and } \\
\text { M. D'Ippolito }\end{array}$ & 2014 & $\begin{array}{l}\text { Innovation accelerators: Defining } \\
\text { characteristics among startup assistance } \\
\text { organizations }\end{array}$ & Report & \\
\hline 23 & $\begin{array}{l}\text { T. Weiblen and H. W. } \\
\text { Chesbrough }\end{array}$ & 2015 & $\begin{array}{l}\text { Engaging with startups to enhance corporate } \\
\text { innovation }\end{array}$ & Journal Article & $\begin{array}{l}\text { California Management } \\
\text { Review }\end{array}$ \\
\hline 24 & R. Harms and S. T. Walsh & 2015 & $\begin{array}{l}\text { An introduction to the field of technology } \\
\text { entrepreneurship: Editorial to the special } \\
\text { issue }\end{array}$ & Journal Article & $\begin{array}{l}\text { Creativity and innovation } \\
\text { management }\end{array}$ \\
\hline
\end{tabular}




\begin{tabular}{|c|c|c|c|c|c|}
\hline \# & AUTHORS & YEAR & TITLE & TYPE & SOURCE \\
\hline 25 & Accenture & 2015 & $\begin{array}{l}\text { Harnessing the power of Entrepreneurs to } \\
\text { Open Innovation - The Digital Collaboration } \\
\text { Index }\end{array}$ & Report & \\
\hline 26 & S. Prashantham and G. S. Yip & 2016 & Engaging with startups in emerging markets & Journal Article & $\begin{array}{l}\text { MIT Sloan Management } \\
\text { Review }\end{array}$ \\
\hline 27 & T. Kohler & 2016 & $\begin{array}{l}\text { Corporate accelerators: Building bridges } \\
\text { between corporations and startups }\end{array}$ & Journal Article & Business Horizons \\
\hline 28 & $\begin{array}{l}\text { R. Cross, R. Rebele and A. } \\
\text { Grant }\end{array}$ & 2016 & Collaborative overload & Journal Article & Harvard Business Review \\
\hline 29 & Y. V. Hochberg & 2016 & $\begin{array}{l}\text { Accelerating entrepreneurs and ecosystems: } \\
\text { The seed accelerator model }\end{array}$ & Journal Article & $\begin{array}{l}\text { Innovation Policy and the } \\
\text { Economy }\end{array}$ \\
\hline 30 & D. K. Kanbach and S. Stubner & 2016 & $\begin{array}{l}\text { Corporate accelerators as recent form of } \\
\text { startup engagement: The what, the why, and } \\
\text { the how }\end{array}$ & Journal Article & $\begin{array}{l}\text { Journal of Applied } \\
\text { Business Research }\end{array}$ \\
\hline 31 & $\begin{array}{l}\text { B. N. Hogenhuis, E. A. van } \\
\text { den Hende and E. J. Hultink }\end{array}$ & 2016 & $\begin{array}{l}\text { When Should Large Firms Collaborate with } \\
\text { Young Ventures? Understanding young } \\
\text { firms'strengths can help firms make the right } \\
\text { decisions around asymmetric collaborations } \\
\end{array}$ & Journal Article & $\begin{array}{l}\text { Research-Technology } \\
\text { Management }\end{array}$ \\
\hline 32 & P. C. Varrichio & 2016 & $\begin{array}{l}\text { Uma discussão sobre a estratégia de inovação } \\
\text { aberta em grandes empresas e os programas } \\
\text { de relacionamento voltados para Startups } \\
\text { no Brasil }\end{array}$ & Journal Article & $\begin{array}{l}\text { Revista de } \\
\text { Administração, } \\
\text { Contabilidade e } \\
\text { Economia da Fundace }\end{array}$ \\
\hline 33 & M. G. Colombo and K. Shafi & 2016 & $\begin{array}{l}\text { Swimming with sharks in Europe: When are } \\
\text { they dangerous and what can new ventures } \\
\text { do to defend themselves? }\end{array}$ & Journal Article & $\begin{array}{l}\text { Strategic Management } \\
\text { Journal }\end{array}$ \\
\hline 34 & $\begin{array}{l}\text { C. Pauwels, B. Clarysse, M. } \\
\text { Wright and J. Van Hove }\end{array}$ & 2016 & $\begin{array}{l}\text { Understanding a new generation incubation } \\
\text { model: The accelerator }\end{array}$ & Journal Article & Technovation \\
\hline 35 & $\begin{array}{l}\text { J.-C. Spender, V. Corvello, } \\
\text { M. Grimaldi and P. Rippa }\end{array}$ & 2017 & $\begin{array}{l}\text { Startups and open innovation: a review of } \\
\text { the literature }\end{array}$ & Journal Article & $\begin{array}{l}\text { European Journal of } \\
\text { Innovation Management }\end{array}$ \\
\hline 36 & $\begin{array}{l}\text { M. Kupp, M. Marval and P. } \\
\text { Borchers }\end{array}$ & 2017 & $\begin{array}{l}\text { Corporate accelerators: fostering innovation } \\
\text { while bringing together startups and large } \\
\text { firms }\end{array}$ & Journal Article & $\begin{array}{l}\text { Journal of Business } \\
\text { Strategy }\end{array}$ \\
\hline 37 & $\begin{array}{l}\text { A. D. Livieratos and P. } \\
\text { Lepeniotis }\end{array}$ & 2017 & $\begin{array}{l}\text { Corporate venture capital programs of } \\
\text { European electric utilities: Motives, trends, } \\
\text { strategies and challenges }\end{array}$ & Journal Article & The Electricity Journal \\
\hline 38 & $\begin{array}{l}\text { C. J. Selig, T. Gasser and G. } \\
\text { H. Baltes }\end{array}$ & 2018 & $\begin{array}{l}\text { How Corporate Accelerators Foster } \\
\text { Organizational Transformation: An Internal } \\
\text { Perspective }\end{array}$ & $\begin{array}{l}\text { Conference } \\
\text { Paper }\end{array}$ & $\begin{array}{l}\text { IEEE International } \\
\text { Conference on } \\
\text { Engineering, } \\
\text { Technology and } \\
\text { Innovation }\end{array}$ \\
\hline 39 & $\begin{array}{l}\text { M. Bogers, H. W. Chesbrough } \\
\text { and C. Moedas }\end{array}$ & 2018 & $\begin{array}{l}\text { Open innovation: research, practices, and } \\
\text { policies }\end{array}$ & Journal Article & $\begin{array}{l}\text { California Management } \\
\text { Review }\end{array}$ \\
\hline 40 & $\begin{array}{l}\text { N. Richter, P. Jackson and T. } \\
\text { Schildhauer }\end{array}$ & 2018 & $\begin{array}{l}\text { Outsourcing creativity: An abductive study of } \\
\text { open innovation using corporate accelerators }\end{array}$ & Journal Article & $\begin{array}{l}\text { Creativity and Innovation } \\
\text { Management }\end{array}$ \\
\hline 41 & $\begin{array}{l}\text { T. Kruft, M. Gamber and } \\
\text { A. Kock }\end{array}$ & 2018 & $\begin{array}{l}\text { Substitutes or Complements? The Role of } \\
\text { Corporate Incubator Support and Innovation } \\
\text { Climate for Innovative Behavior in the } \\
\text { Hosting Firm }\end{array}$ & Journal Article & $\begin{array}{l}\text { International Journal of } \\
\text { Innovation Management }\end{array}$ \\
\hline 42 & $\begin{array}{l}\text { R. K. Shankar and D. A. } \\
\text { Shepherd }\end{array}$ & 2018 & $\begin{array}{l}\text { Accelerating strategic fit or venture } \\
\text { emergence: Different paths adopted by } \\
\text { corporate accelerators }\end{array}$ & Journal Article & $\begin{array}{l}\text { Journal of Business } \\
\text { Venturing }\end{array}$ \\
\hline 43 & $\begin{array}{l}\text { S. Brunswicker and } \mathrm{H} \text {. } \\
\text { Chesbrough }\end{array}$ & 2018 & $\begin{array}{l}\text { The Adoption of Open Innovation in Large } \\
\text { Firms }\end{array}$ & Journal Article & $\begin{array}{l}\text { Research-Technology } \\
\text { Management }\end{array}$ \\
\hline
\end{tabular}




\begin{tabular}{|c|c|c|c|c|c|}
\hline \# & AUTHORS & YEAR & TITLE & TYPE & SOURCE \\
\hline 44 & $\begin{array}{l}\text { S. B. Mahmoud-Jouini, C. } \\
\text { Duvert and M. Esquirol }\end{array}$ & 2018 & $\begin{array}{l}\text { Key Factors in Building a Corporate } \\
\text { Accelerator Capability: Developing an } \\
\text { effective corporate accelerator requires } \\
\text { close attention to the relationships between } \\
\text { startups and the sponsoring company }\end{array}$ & Journal Article & $\begin{array}{l}\text { Research-Technology } \\
\text { Management }\end{array}$ \\
\hline 45 & \begin{tabular}{|l|} 
W. Hora, J. Gast, N. Kailer, \\
A. Rey-Marti and A. Mas-Tur
\end{tabular} & 2018 & $\begin{array}{l}\text { David and Goliath: causes and effects of } \\
\text { coopetition between start-ups and corporates }\end{array}$ & Journal Article & $\begin{array}{l}\text { Review of Managerial } \\
\text { Science }\end{array}$ \\
\hline 46 & S. Alänge and A. Steiber & 2018 & $\begin{array}{l}\text { Three operational models for ambidexterity } \\
\text { in large corporations }\end{array}$ & Journal Article & Triple Helix \\
\hline 47 & S. Blank & 2019 & $\begin{array}{l}\text { Why Companies Do "Innovation Theater" } \\
\text { Instead of Actual Innovation }\end{array}$ & $\begin{array}{l}\text { Electronic } \\
\text { Article }\end{array}$ & \\
\hline 48 & S. Kaplan & 2019 & $\begin{array}{l}\text { How Big Companies \& Startups Use "Co- } \\
\text { Creation" to Innovate }\end{array}$ & $\begin{array}{l}\text { Electronic } \\
\text { Article }\end{array}$ & \\
\hline 49 & C. Minsky & 2019 & $\begin{array}{l}\text { Big corporates are only interested in } \\
\text { "innovation theatre" }\end{array}$ & $\begin{array}{l}\text { Electronic } \\
\text { Article }\end{array}$ & \\
\hline 50 & Y. Striletskyi & 2019 & $\begin{array}{l}\text { The biggest challenges of scaling for startups } \\
\text { and how to tackle them }\end{array}$ & $\begin{array}{l}\text { Electronic } \\
\text { Article }\end{array}$ & \\
\hline 51 & J. Lawton & 2019 & $\begin{array}{l}\text { What to expect from your corporate } \\
\text { accelerator }\end{array}$ & $\begin{array}{l}\text { Electronic } \\
\text { Article }\end{array}$ & $\begin{array}{l}\text { Innovation Leader } \\
\text { Pointers }\end{array}$ \\
\hline 52 & B. R. Wikhamn and A. Styhre & 2019 & $\begin{array}{l}\text { Corporate hub as a governance structure for } \\
\text { coupled open innovation in large firms }\end{array}$ & Journal Article & $\begin{array}{l}\text { Creativity and Innovation } \\
\text { Management }\end{array}$ \\
\hline 53 & M. Kötting & 2019 & $\begin{array}{l}\text { Corporate incubators as knowledge brokers } \\
\text { between business units and ventures }\end{array}$ & Journal Article & $\begin{array}{l}\text { European Journal of } \\
\text { Innovation Management }\end{array}$ \\
\hline 54 & $\begin{array}{l}\text { B. Tabrizi, E. Lam, K. Girard } \\
\text { and V. Irvin }\end{array}$ & 2019 & Digital transformation is not about technology & Journal Article & Harvard Business Review \\
\hline 55 & $\begin{array}{l}\text { S. Prashantham and K. } \\
\text { Kumar }\end{array}$ & 2019 & Engaging with startups: MNC Perspectives & Journal Article & $\begin{array}{l}\text { IIMB Management } \\
\text { Review }\end{array}$ \\
\hline 56 & $\begin{array}{l}\text { M. P. Allmendinger and E. S. } \\
\text { C. Berger }\end{array}$ & 2019 & $\begin{array}{l}\text { Selecting corporate firms for collaborative } \\
\text { innovation: entrepreneurial decision making } \\
\text { in asymmetric partnerships }\end{array}$ & Journal Article & $\begin{array}{l}\text { International Journal of } \\
\text { Innovation Management }\end{array}$ \\
\hline 57 & J. K. Groote and J. Backmann & 2019 & $\begin{array}{l}\text { Initiating open innovation collaborations } \\
\text { between incumbents and startups: How can } \\
\text { David and Goliath get along? }\end{array}$ & Journal Article & $\begin{array}{l}\text { International Journal of } \\
\text { Innovation Management }\end{array}$ \\
\hline 58 & T. Kruft and A. Kock & 2019 & $\begin{array}{l}\text { Towards a comprehensive categorization of } \\
\text { corporate incubators: Evidence from cluster } \\
\text { analysis }\end{array}$ & Journal Article & $\begin{array}{l}\text { International Journal of } \\
\text { Innovation Management }\end{array}$ \\
\hline 59 & A. Onetti & 2019 & $\begin{array}{l}\text { Turning open innovation into practice: trends } \\
\text { in European corporates }\end{array}$ & Journal Article & $\begin{array}{l}\text { Journal of Business } \\
\text { Strategy }\end{array}$ \\
\hline 60 & J. Gonthier and G. M. Chirita & 2019 & $\begin{array}{l}\text { The role of corporate incubators as } \\
\text { invigorators of innovation capabilities in } \\
\text { parent companies }\end{array}$ & Journal Article & $\begin{array}{l}\text { Journal of Innovation and } \\
\text { Entrepreneurship }\end{array}$ \\
\hline 61 & $\begin{array}{l}\text { G. D. Lauritzen and M. } \\
\text { Karafyllia }\end{array}$ & 2019 & $\begin{array}{l}\text { Perspective: leveraging open innovation } \\
\text { through paradox }\end{array}$ & Journal Article & \begin{tabular}{|l} 
Journal of Product \\
Innovation Management
\end{tabular} \\
\hline 62 & B. R. Wikhamn & 2019 & $\begin{array}{l}\text { Open innovation change agents in large } \\
\text { firms: how open innovation is enacted in } \\
\text { paradoxical settings }\end{array}$ & Journal Article & R\&D Management \\
\hline 63 & R. Freytag & 2019 & $\begin{array}{l}\text { Strategic negotiations: three essentials for } \\
\text { successful partnerships with startups }\end{array}$ & Journal Article & Strategy \& Leadership \\
\hline 64 & Innovation Leader & 2019 & $\begin{array}{l}\text { Startup engagement: best practices for large } \\
\text { organizations (report excerpt) }\end{array}$ & Report & \\
\hline 65 & $\begin{array}{l}\text { M. Portincaso, A. d. 1. Tour } \\
\text { and P. Soussan }\end{array}$ & 2019 & The Dawn of the Deep Tech Ecosystem & Report & \\
\hline 66 & $\begin{array}{l}\text { Z. Younis, A. Desai and M. } \\
\text { Sigal }\end{array}$ & 2019 & $\begin{array}{l}\text { Unlocking innovation through startup } \\
\text { engagement: best practices from leading } \\
\text { global corporations }\end{array}$ & Report & \\
\hline
\end{tabular}

